Article

\title{
Environmental Management and Sustainable Labels in the Ski Industry: A Critical Review
}

\author{
Stefano Duglio ${ }^{1,2, *}$ and Riccardo Beltramo ${ }^{1,2}$ \\ 1 Department of Management, University of Turin, 218 bis, Corso Unione Sovietica, 10134 Turin, Italy; \\ riccardo.beltramo@unito.it \\ 2 NatRisk-Research Centre on Natural Risks in Mountain and Hilly Environments, University of Turin, \\ 218 bis, Corso Unione Sovietica, 10134 Turin, Italy \\ * Correspondence: stefano.duglio@unito.it; Tel.: +39-11-670-57-16
}

Academic Editor: Alessandro Ruggieri

Received: 24 May 2016; Accepted: 18 August 2016; Published: 26 August 2016

\begin{abstract}
Sustainability is increasing in importance in relation to the competitiveness of winter tourism, particularly when considering mountain destinations. Exploring in more detail winter tourism related to ski resorts, operators are especially concerned about environmental issues caused by climate change. Therefore, they have gradually become aware of the importance of finding adequate solutions to cope with such issues as well as being able to sensitize tourists. The main goal of this paper is to analyze the different sustainable tools that can be adopted by the ski industry. In this field there appear to be two main approaches. The first line is that of sustainable labels being applied to local ski resorts; whereas the second consists in operators-such as the managers of cable cars-making use of specific labels or management systems that are environmentally oriented.
\end{abstract}

Keywords: ski industry; environmental management; sustainability; eco-labels

\section{Introduction}

The issues related to environmental sustainability are becoming an increasingly critical factor impacting the competitiveness of the ski industry, affecting resorts of all sizes. In the last few years, the most important determinant of this increasing awareness is probably due to the consequences of climate change on mountain regions and, consequently, on the ski industry. It has been some time since this activity has been considered by international bodies as being one of the most vulnerable to climate change [1,2], although some authors have been studying this phenomenon and its implications for tourism and evaluating the implications of climate change for ski resorts and the responses adopted by the organizations in Europe [3-9], North America [10-13], Asia [14,15], Australia, and New Zealand [16,17]. Among all the "adaptive" strategies adopted by ski resorts-divided into technical, economic policy, institutional, managerial, planning, legal, and behavioral [18,19]—and in particular thanks to snowmaking installations [20-22], it has been partly possible to cope with the problem posed by the shortened ski season due to the lack of natural snow. Some researchers, basing their findings on provisional models for North American tourist destinations, affirm that not all mountain resorts will necessarily be interested in the phenomenon of climate change; consequently, the impact on the ski season may, in some cases, be only moderate $[10,11,23]$. Modelling two different climate change scenarios for three ski resorts in Québec, Scott et al. [11] report that in accordance with the warmest scenario the ski season losses for the 2020 s varied from $13 \%$ to $15 \%$ and concluded that even the warmest climate change hypothesis "poses only a very minor risk to ski operations at each of the three study areas". Similar conclusions [10] are highlighted for four out of six ski resorts in Eastern North America. In this context, snowmaking is able to increase the number of skiable days, reducing, by contrast, the vulnerability of the ski resorts [20,24]. The same studies, however, 
assert that the concurrence of several factors [11], including the location and above all the economic and environmental stress deriving from the intense use of snowmaking, will pose a critical threat to the economic sustainability of several ski resorts in the coming years [5,25]. As Abegg et al. [26] point out, the costs of snowmaking are important, especially for the small and medium-size installations, and can be divided into three different factors: investment, operational, and maintenance costs. According to Hahn [27], $1 \mathrm{~m}^{3}$ of artificial snow (including amortization, energy, and personnel costs) has a cost between EUR 3 and 5 and in Switzerland, for instance, for each km of ski run, an investment of about EUR 650,000 is considered normal. Steiger and Mayer [28] report how in the winter season of 2006-2007, the Tyrolean ski industry invested EUR 55 million in snowmaking. Pickering and Buckley [16], using as a parameter a cost of US $\$ 131,000$ for a single snow gun, estimate US $\$ 82$ million in investments in the snowmaking infrastructure for six main resorts of the Australian Alps (without taking into account water and energy costs). In their study of six main ski resorts in Eastern North America, furthermore, Scott et al. [10] point out two different scenarios: the 2020s and the 2050s. In the 2050s high impact scenario, "snowmaking costs more than doubled at 4 of the study areas": from Québec City (105\%, in Québec) to Thunder Bay (146\%, in Ontario).

Moreover, snowmaking seems to contradict both the general political consensus concerning the need to mitigate the effects of climate change and the paradigm of sustainable tourism [29], formally inaugurated by the Charter of Lanzarote in 1995 and further defined by the World Tourism Organization-United Nations Environment Programme (UNWTO-UNEP) [30]. In fact, as far as the environmental implications of snowmaking are concerned, it is possible to identify two main aspects among the others: water consumption and energy consumption. In its last report, the Commission Internationale pour la Protection des Alpes (CIPRA) [31], citing a previous work carried out by Teich [32], reports that one hectare of technical snow (with a thickness of $30 \mathrm{~cm}$ ) needs between 600,000 and 1.5 million liters of water and between 5000 and 27,000 kWh of electricity.

When confronted with such an important theme, operators answer with different messages. Trawöger [33] shows that the main stakeholders in the ski industry in the mountain area of Tyrol are not unduly worried about climate change, not having perceived this phenomenon as a danger. Climate change is supposed to produce repercussions on a global rather than on a local scale and innovation in the field of snowmaking is considered adequate to compensate for the absence of natural snow [10,34]. On the other hand, in their conclusions, Morrison and Pickering [22] point out how the winter tourism industry is aware that the perceptions of their vulnerability to climate change are more damaging than the impacts; the industry concentrates its attention especially on marketing strategies able to communicate to stakeholders their ability to cope with climate change thanks to the snowmaking technologies. These results are similar to those found in a previous study by Bicknell and McManus [35].

In fact, some studies underline the importance of reliable snow conditions for skiers [36] and the behavior of the experienced and core skiers to engage in spatial substitution [13], concentrating to those ski resorts that are still operable. Moreover, not only do tourists take into consideration the reliability of the snow conditions, but they also start to pay attention to the social and environmental dimensions of sustainability. According to Hopkins' conclusions [37], snowmaking may be viewed, in the long term, as a (mal) adaptive strategy, in the sense that "it may exacerbate the underlying causes of climate change".

In order to face the present and future threats, the ski industry may rely on tools created to implement the concept of sustainability in the business activity: the Management Systems (MSs) standards and ecolabels. In fact, the MSs standards and ecolabels consider greenhouse gas emission as an environmental variable to control and improve and can help the ski industry in minimizing the environmental impact as well as communicating to tourists this awareness. As a consequence of the extension of the sustainability concept to the tourist sector, the application of MSs standards and ecolabels - which were initially intended for industrial activities-has been extended to the tourist sector itself. Gradually, these tools have become useful for any type of tourist activity, including ski resorts and installations. In accordance with these general considerations, this work is organized as follows. 
Section 2 contains the literature review concerning firstly the environmental tools implemented in the hospitality industry and secondly focusing on the ski industry.

Section 3 deals with the general aim and the methodological approach of the study.

Section 4 reports and discusses the results, concentrating its attention on the comparison of the different environmental tools available for the ski industry.

Finally, the conclusions present the strong points as well as the limitations of the research, pointing the way for further researches.

\section{Literature Review}

\subsection{Environmental Management Tools in the Hospitality Industry}

The issue of the environmental dimension of sustainability has benefited from a strong attention to hospitality research [38-40]. The reasons why a hotel may be interested in this theme are ascribable to three main factors: manager's disposition [41], affiliation to a hotel's chain [42], or the location of the hotel [43].

Independent of the motivations, in this field, particular attention has been paid to the development and implementation of two main types of tools.

On the one hand, attention has been given to the design of management tools which are in compliance with international standards (especially ISO 14001:2015 Standard [44] and EMAS-Eco Management and Audit Scheme-Regulation [45]) and which are also capable of being implemented in the tourism industry [46]. These standards, formulated with reference to a specific policy goal, necessitate the creation of a management system, which is divided into four phases according to the Deming Cycle methodology: Plan, Do, Check, and Act [47-49]. The relationship between hospitality, tourism, and environmental and/or sustainable systems is widely debated and sometimes criticized [50-54]. As far as environmental certifications are concerned, Marimon et al. [55] show that in the hotels and restaurant section of the European Accreditation code (EAC), the number of such certifications rose from 105 in 1998 to 1,078 in 2008, showing an increasing interest by operators in this sector. Only Italy achieves, in 2016, 573 ISO 14001 certifications in this specific sector [56]. With respect to EMAS, there were only 28 hotels and 10 camps meriting this award [57].

On the other hand, researchers in the field of hospitality have shifted their attention to other types of tools such as ecolabels [58,59]. Ecolabels provide some benefits for the tourist industry, and more generally for society, in terms of image, competitiveness, and quality [60] in order to mitigate the negative effects of tourism [59]. Within the past 20 years, however, there was a proliferation of these kind of tools [58] and, according to Font [61], by the late 1990s, there were already more than 100 ecolabels for tourism, hospitality, and ecotourism. More recently, Ecotrans (an independent non-profit European network of experts and organizations), in its dedicated Internet portal (Destinet), reports more than 100 ecolabels for sustainable tourism all over the world. This general development has also specifically aroused interest in the mountain "environment". The hotel industry, therefore, has witnessed the proliferation of many different "eco-friendly", "quality", or "sustainable" labels; however, such myriad instruments, with their different scopes and criteria, have historically caused confusion to guests [62]. Furthermore, in some cases such labelling has been specifically focused on the lodging sector [63], also taking into consideration mountain facilities such as mountain huts [64-66], highlighting both the strong and weak points in their application [67].

\subsection{Environmental Management Tools for the Ski Industry}

If attention is specifically paid to the ski industry, during the past years, emphasis has been devoted to the relationship between environmental sustainability and the mountain/ski resorts [68-70], in some cases related to the visitors' perceptions of the Voluntary Environmental Programs (VEPs) [71,72].

As far as the VEPs for the ski industry (MSs or eco-labels) are concerned, some scholars concentrate their attention on evaluating the implementations of a specific tool [73-76], and few studies aim at 
analyzing simultaneously the different adoptable tools [77,78]. In this field, however, it is possible to note some similarities in the types of tools that can be used by the ski operators. In fact, the ski industry can implement tools strictly designed for ski lifts, cable cars, etc. and also models useful for ski resorts, taking into consideration management systems as well as eco-labels devoted to sustainability.

\section{Materials and Methods}

The paper aims at analyzing the different "sustainable" tools that can be adopted by the ski industry. Although several attempts have been carried out to compare different instruments, or at least the most representative ones [62], great difficulty in carrying out this exercise persists. This is probably due to the absence of a common standard that can provide both a univocal methodological approach (for example, giving criteria based on the Life Cycle Assessment methodology) and a common terminology $[77,78]$. This non-homogeneity in the adopted tools implies some difficulties in deciding which of them are useful to the ski industry. A second consequence of the confusion in this area stems from the lack of communication about environmental awareness to stakeholders, above all tourists.

In the analysis of the different tools available to the ski industry, starting from the classification provided by Luthe [77], a comparative approach was adopted, in order to allow for the comparison of common points as well as the identification of some critical aspects.

The analysis proposed in the results and discussion is not representative of the global ski industry. In fact, we decided to pay particularly attention to those tools that are adopted or are adoptable by ski resorts rather than tools and labels relevant for a specific part of a resort. As far as the geographical extension is concerned, the reference environment of the analysis is the Alps. In this general framework, the label Sustainable Slopes, sponsored by the American National Ski Areas Association, represents the unique exception, for two main reasons. Firstly, it is the only label specifically focused on the ski resort, with a deep analysis of the typical ski resorts' processes, and, secondly, for the large adhesion showed by the operators.

\section{Results and Discussion}

Two main approaches are recognizable: some tourist destinations rely on the application of sustainable labels to a mountain resort whereas other destinations depend on environmental systems that can be adopted by the management of a cable car or a mountain municipality. Furthermore, there are some tools specifically focused on the audit phase (Audit Process) or on the communication process (Global reporting Initiative); however, with respect to the latter, there are no available examples of implementation in the ski industry and, therefore, the issue is not addressed in this work.

All these tools, however, can be considered as VEPs.

Table 1 identifies the most important tools, whereas Figure 1 shows the same tools, separated according to area of application.

Table 1. Sustainable tools for the ski industry.

\begin{tabular}{cccc}
\hline Tools & Name & Application & $\begin{array}{c}\text { Aspects Taken into } \\
\text { Account }\end{array}$ \\
\hline \multirow{2}{*}{ Management systems } & ISO 14001 Standard [44] & Company/territorial area & Environment \\
& ISO 50001 Standard [79] & $\begin{array}{c}\text { Company/territorial area } \\
\text { Company/territorial area }\end{array}$ & $\begin{array}{c}\text { Envery } \\
\text { Environment }\end{array}$ \\
& EMAS Regulation [45] & Somi resort & Environment \\
& Sustainable Slopes & Skinainability \\
Eco-labels & Flocon Vert & Ski resort & Sustainability \\
& Alpine Pearls & Ski resort & Sustainability \\
\hline Audit Process & Green Globe & Ski resort & Environment \\
\hline Reporting & Pro-natura pro ski & Ski resort & Sustainability \\
\hline & Global Report Initiative ${ }^{1}$ & Company &
\end{tabular}




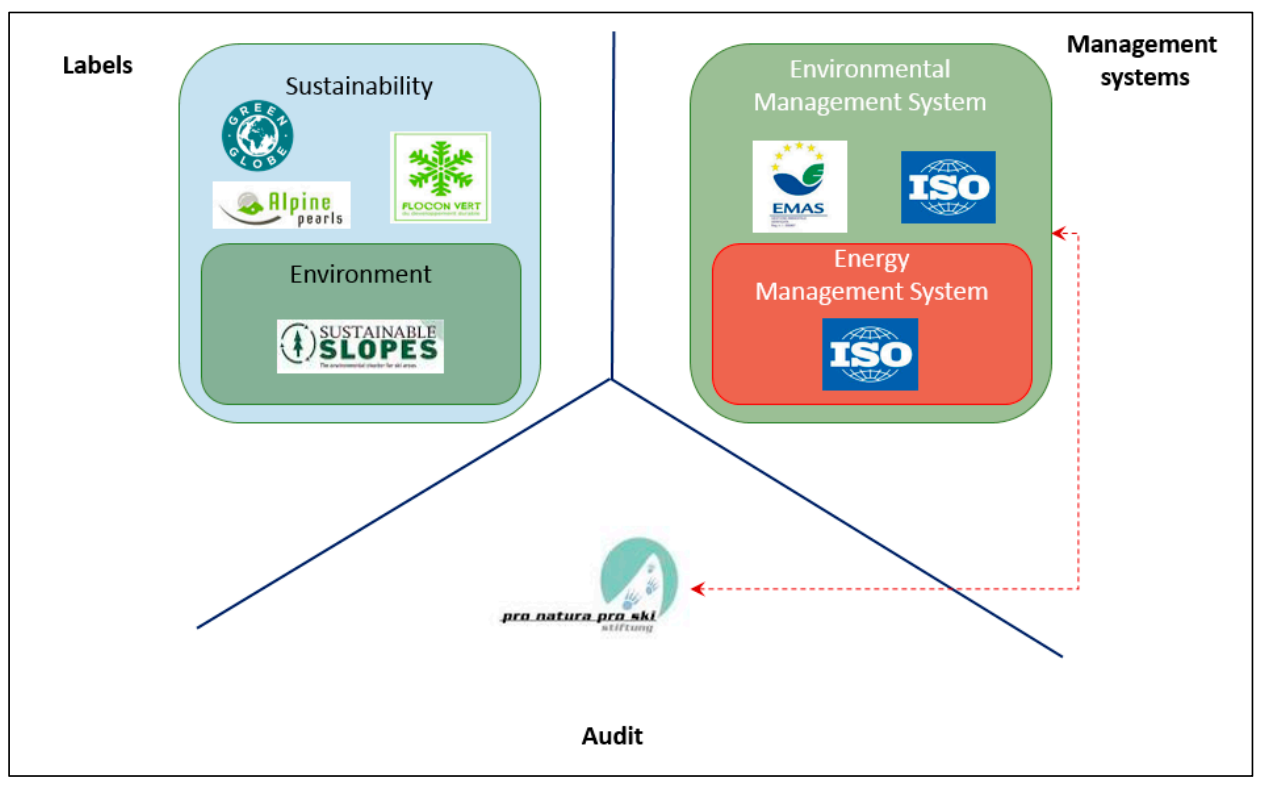

Figure 1. Sustainable tools for the ski industry and their area of application.

\subsection{Systems for Environmental Management}

It is possible to identify three different tools in this field: the ISO 14001:2015 Standard [44] on Environmental Management Systems, the European Eco-Management and Audit scheme (EMAS) Regulation 1221/2009 [45], and the ISO 50001:2011 Standard [79], focused on the Energy Management System. All of these tools are founded on the Deming Cycle approach, under the umbrella of continual improvement. The most important distinction between ISO 14001 and EMAS is represented by the different degree to which the organization's environmental profile is required to be communicated to stakeholders.

In fact, EMAS Regulation requests the issuance of an Environmental Declaration, containing the details of the processes, the assessment of the environmental variables, and the organizational objectives and targets. By contrast, in the ISO 14001 context [44], the organization has to publish to the citizens a general Environmental Policy, containing the general vision of the top management on the environment. As far as ISO 50001 [79] is concerned, this standard provides a framework of requirements for organizations to achieve a number of energy-oriented goals: to develop a policy for the more efficient use of energy, to use data to better calculate energy consumption, to measure the results of such consumption, and to identify new targets and objectives for the management of energy. As already mentioned, these tools can be adopted by the management of cable cars as well as mountain municipalities. In the first case, the application of these standards by the ski industry showed a low level of adherence (in Italy, for example, the most recent official data by Accredia [56] reported only five cable cars with an Environmental Management System certified according to ISO 14001 [44], four of which were in the Trentino Alto Adige Region).

In the second case, the adoption of ISO 14001 [44] by the municipalities has witnessed an interesting evolution (in Italy, there are about 260 Municipalities certified as compliant with ISO 14001 EMS [56], 176 with EMAS [57]), and only one with ISO 50001 [56]); there are now several mountain municipalities involved in the process of achieving environmental compliance, even where they do not directly run ski installations [55].

Furthermore, with the new edition of the ISO in 2015, several structural innovations were introduced, including the life cycle perspective and the risk assessment [44]. In particular, this last issue is defined as the condition of uncertainty in reaching the environmental objectives and it can be divided into two main categories: risks for the environment and risks for the organization [80]. As far as the life cycle perspective is concerned, the analysis of the environmental aspects of the processes 
should take into consideration the effects in terms of macro-categories of environmental impacts (greenhouse emission, eutrophication, etc.) [44], even if it is not necessary the application of the Life Cycle Assessment (LCA) methodology [81].

\subsection{Eco-Labels for the Ski Industry}

With respect to eco-labels, it is possible to note a global paucity of tools specifically drafted for the ski industry. Apart from the most important label for the European context-the European Ecolabel which, due to its revision in 2001, will eventually become applicable to accommodation-it is significant that all the relevant tools for the ski industry are related to tourist destinations rather than a single company or cable car. Therefore, the following labels are reviewed in the next few paragraphs: Sustainable Slopes, Alpine Pearls, Flocon Verts, and Green Globe.

\subsubsection{Sustainable Slopes}

Sustainable Slopes is a project as well as a label sponsored by the National Ski Areas Association (NSAA). NSAA is an American trade association for operators and owners of ski areas covering 325 alpine resorts and representing more than 90 percent of the skier/snowboarder visits nationwide. The Sustainable Slopes project was adopted by the ski industry in 2000 and nowadays there are some 190 resorts participating in the program [82]. The Sustainable Slopes label consists of an Environmental Charter comprising a set of 21 principles and, for each of them, certain specific actions (called "Options for getting there") are requested. The direct consequence of this process is exemplified by the development of definitions of environmental programs.

Therefore, having regard to their specific characteristics, ski resorts can choose from among them. As the Association reports, the aim of the Charter is not to limit the development of the ski industry, but to define some useful rules for regulating its operation.

This may be the reason why some authors consider it a greenwashing tool or at least a public relations scheme [73]. Studies on this tool seem to be contradictory. On the one hand, after their five-year study Rivera et al. [74] point out how there is not statistical evidence that the ski areas joining the program have higher overall environmental performance or higher scores compared to nonparticipants in the field of pollution management, wildlife, and habitat management. The only statistically significant correlation seems to be related to the higher natural resource conservation performance rates [74]. On the other hand, a study on 20 operators published in 2003 shows the role of the Charter in raising ski industry awareness on the relationship between its activities and the environment [75].

\subsubsection{Alpine Pearls}

Alpine Pearls is a label of recent creation, thanks to the development of two different European Union Projects by the Austrian Ministry of Agriculture, Forestry, Environment, and Water Management. Both of them are focused on sustainable mobility as a tool to be adopted by mountain municipalities in order to cope with the consequences of climate change in the Alps. The final goal of this label is the creation of a wide network for sustainable mobility- and eco-friendly tourism thanks to a communication and cooperation platform and with the creation, dated 2014, of a network for accommodation establishments [83].

The label specifies two types of criteria, mandatory and "objectives", divided into five fields [84]:

- mobility, with 16 mandatory and eight "objectives" criteria;

- environmental quality, with five mandatory and four "objectives" criteria;

- nature-biodiversity, with one mandatory and three "objectives" criteria;

- feel-good quality, with five mandatory and five "objectives" criteria;

- regional economy and food, with two mandatory and five "objectives" criteria. 
Therefore, the criteria consider simultaneously the environmental, economic, and social dimensions of sustainability. The "objectives" criteria are intended to provide the municipalities with the opportunity to enhance specific areas. Furthermore, there is a precise intention to consider the effects of tourist installations and certain of the mandatory criteria are specifically aimed at evaluating and minimizing the environmental consequences of the linked ski area. Alpine Pearls, therefore, can be considered a hybrid label because, even if mandatory criteria were elaborated for tourist installations specifically connected with winter tourism, the vision of the tool is related to the territorial area as a whole with a prevalent focus on mobility. At the beginning, there were 17 municipalities involved in the process; that number rose to 30, spread over seven different countries, half of which are located in the Italian North Regions.

\subsubsection{Flocon Vert}

Flocon Vert is a label for mountain resorts created in 2011 by the Mountain Riders Association. This label has actually excited the interest of four mountain resorts: Villars, in the Swiss massif of the Alpes Vaudoises, Les Rousses, Chatel Portes du Soleil and the Vallée de Chamonix-Mont-Blanc, in the French Alps. Flocon Vert aims at being a tool for the sustainable development of mountain resorts, with a specific focus on winter destinations. In order to join the label, it is necessary to prepare a dossier and surrender to an audit visit carried out by a third, and independent, body. The label takes into consideration 31 main criteria (core) and 11 "bonus" (optional) criteria: this last type of criteria, however, are destined to become "core" for the same resort in the following years. Not only does the label include environmental aspects, but also social ones. The core and bonus criteria are divided into seven categories: transport, planning, energy, water, waste, social, and territory [85].

\subsubsection{Green Globe}

Green Globe is the label for sustainable travel and tourism. It was created in 1992 after the United Nations Rio de Janeiro Earth Summit in 1992 and it is based on the Agenda 21 principles. In 2008, an American company bought Green Globe and the certification is now known as EarthCheck (EC) [86]. The Green Globe Standard includes 41 core criteria divided into four main sections: Sustainable Management, Environment, Social/Economic, and Cultural Heritage [87]. The applicable indicators vary by type of certification, geographical area as well as local factors. The conformity with Green Globe Certification's standard is verified by an independent organization (third party), according to the international standard ISO 19011 [88] (Guidelines for auditing management systems). Apart from the ISO 19011, Green Globe is also based on ISO 14001 and ISO 9001 (Quality management systems-requirements) [87].

This label is adopted by one mountain resort: Tigne in the French Alps that joined the certification program in November 2015 [87].

\subsection{Audit Process}

The Pro Natura-Pro Ski Foundation was established in 1999. Its principal goal is studying the relationships between the ski industry and the environment. Starting from this general aim, the foundation is carrying out a project focused on Eco-Audits in ski areas, which are envisaged as useful tools for checking the impact of the ski industry on the environment. This activity is being carried out in collaboration with the Austrian University of Bodenkultur, Institut für Landschaftsentwicklung, Erholungs-und Naturschutzplanung (Institute for the Development of Landscape, Tourism, Conservation and Plan of the Environment). The methodology is strictly connected with the logic of environmental management systems and is congruent with ISO and EMAS; it thereby validates the Deming Cycle approach, which, in this case, is divided into environmental policy, environmental assessment, program, management system, and environmental declaration [89]. Until now, this process has been applied to five areas, two in Austria, and one each in Germany, France, and Switzerland. 
Figures 2 and 3 show the comparison of the aforementioned tools, highlighting the common points related to the three pillars of sustainability (environment, social, and economy) and the systemic approach (if present).

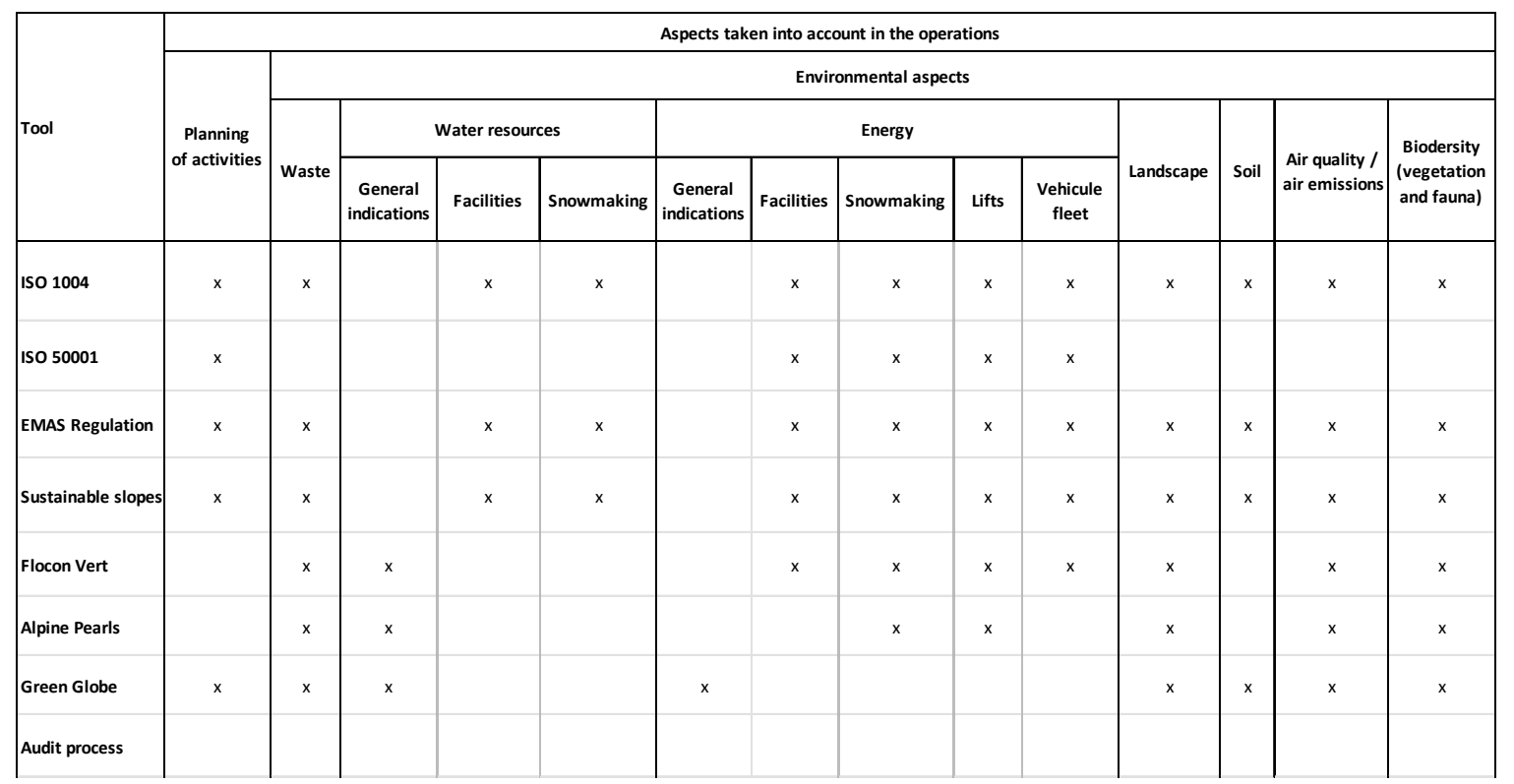

Figure 2. Tools for the ski industry: A comparison on environmental aspects.

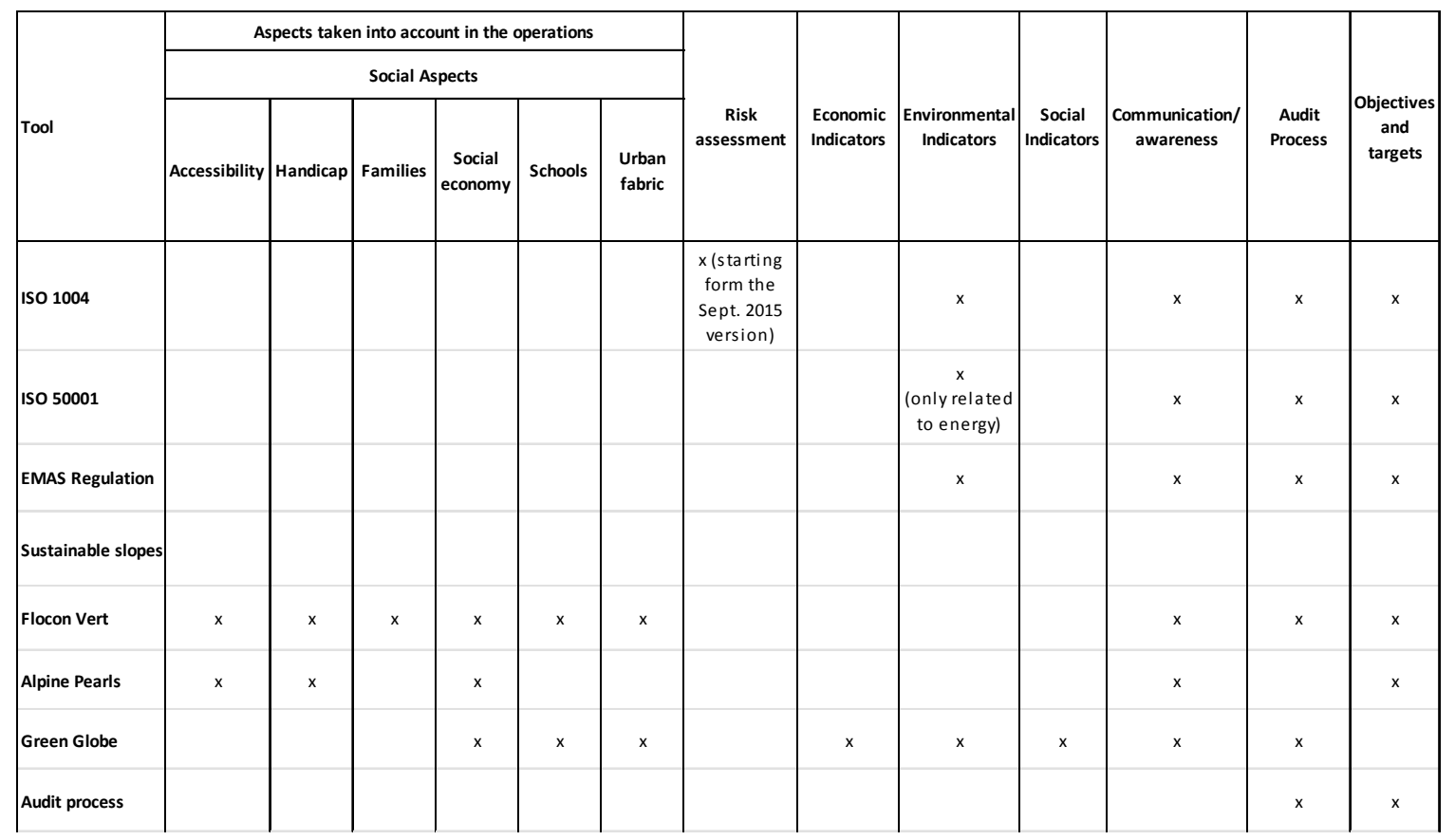

Figure 3. Tools for the ski industry: A comparison on social aspects and communication strategies.

As reported in Figures 2 and 3, each tool is capable of considering the environmental implications of the different activities related to a ski area. The selected level of analysis depends on the specific aim of the tool under consideration. Sustainable Slopes and Flocon Vert are labels specifically created for ski areas and necessitate a deep analysis of the typical processes related to skiing. If confronted, it is possible to affirm that Sustainable Slopes appears to be more complete in its analysis of the core 
processes related to the ski resorts. In fact, it recognizes all the environmental implications of the operational processes, divided into snowmaking, facilities, lifts, and vehicle fleet (where necessary), taking into account in the meantime the planning, design, and construction of the trails, base areas and facilities. On the other hand, it covers only one dimension of sustainability. Therefore, even if the Flocon Vert seems to be less complete in the core processes analysis and their ecological implications it adds seven social requirements connected to accessibility, family, seasonal employers, and handicap, showing a wider approach.

As previously mentioned, the Green Globe label was not specifically created for ski resorts but more generally for sustainable tourism. The presence of the first certified ski resort may be a starting point for the development of this label in this kind of activity. In fact, not only does Green Globe cover a wide range of environmental (17 elements) and social/economic (13 elements) criteria, but also considers the most important MSs in its structure (Quality Management System and Environmental Management System). Therefore, it is no wonder that the first set of criteria, containing nine elements, has been called Sustainable Management and, among them, the first two criteria are about the necessity to implement a long-term sustainability management system and legal compliance. These two last concepts are the core of an environmental MS certification in accordance with 14001 Standard or the EMAS Regulation. Therefore, Green Globe appears to address the dynamic approach typical of the MSs, useful in order to operate and reach environmental objectives and targets, but also for communicating the managerial policy, creating a sort of hybrid model between MS and label.

\section{Conclusions}

In conclusion, all the tools considered in the study contained both strong and weak points. At the same time, it seems that there is not a tool able to deal completely with the concept of sustainability.

It is the authors' opinion that the 2015 edition of the ISO 14001 [44] may become an important tool for management thanks to its new perspective. In fact, it is the life cycle perspective that can help the operators of the ski industry to better understand the relationship between the processes and the macro-categories of environmental impacts, especially in terms of climate change, which is one of the most debated topics among researchers. Moreover, it might help to fill the aforementioned gaps about the common terminology and the univocal methodological approach, underlined by Luthe $[77,78]$. Secondly, the risk-based system may also help the operators to evaluate risks not only for the environmental consequences, but also for the company itself in terms of business continuity, corporate image, etc.

As mentioned previously, the environmental management should be integrated with indicators regarding social aspects in order to have a more complete perspective of all the issues concerning the ski area.

The paper aims at presenting a first analysis of the tools available to the ski industry, starting from the consideration that environmental concerns will stimulate innovation and that innovation itself can be divided into technical and managerial innovation. Not only is the analysis of the "state of the art" useful for comparing tools, but also in order to draft new trends in the evolution to a risk-based system.

As with all research, this study contains some limitations. First of all, it should be completed by an "in the field" analysis of selected case studies.

Furthermore, research should be focused on actual case studies for the purpose of assessing the perception of these tools by ski industry operators and tourists themselves. As far as tourists are concerned, in their study at the Mt. Bechelor ski area, Little and Needham point out that most skiers and snowboarders are not highly knowledgeable of VEPs [71].

Author Contributions: The authors contributed full and equally to this work. Both authors contributed to research design and have read and approved the final manuscript.

Conflicts of Interest: The authors declare no conflict of interest. 


\section{Abbreviations}

The following abbreviations are used in this manuscript:

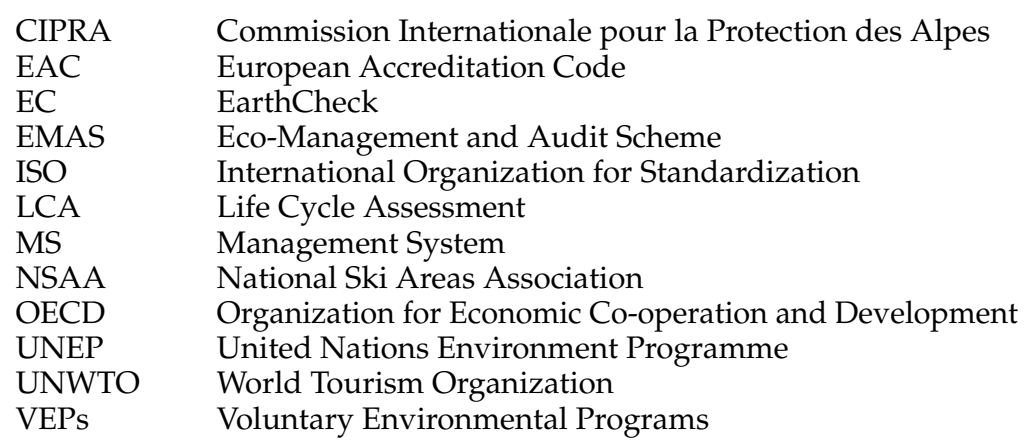

\section{References}

1. World Tourism Organization (UNWTO). Climate Change and Tourism; World Tourism Organization (UNWTO): Djerba, Tunisia, 2003.

2. World Tourism Organization (UNWTO); United Nations Environment Programme (UNEP). Climate Change and Tourism. Responding to Global Challenges; UNWTO: Madrid, Spain; UNEP: Paris, France, 2008.

3. Müller, H.; Weber, F. Climate change and tourism-scenario analysis for the Bernese Oberland in 2030. Tour. Rev. 2008, 66, 57-71. [CrossRef]

4. Richard, D.; George-Marcelpoil, E.; Boudieres, V. Climate change and the development of mountain areas: What do we need to know and for what types of action? J. Alp. Res. 2010, 98, 2-13. [CrossRef]

5. Steiger, R. The impact of snow scarcity on ski tourism: An analysis of the record warm season 2006/2007 in Tyrol (Austria). Tour. Rev. 2011, 66, 4-13. [CrossRef]

6. Elsasser, H.; Messerli, P. The vulnerability of the snow industry in the Swiss Alps. Mt. Res. Dev. 2001, 21, 335-339. [CrossRef]

7. Soboll, A.; Dingenldey, A. The future impact of climate change on Alpine winter tourism: A high-resolution simulation system in the German and Austrian Alps. J. Sustain. Tour. 2012, 20, 101-120. [CrossRef]

8. Moen, J.; Fredman, P. Effects of climate change on Alpine skiing in Sweden. J. Sustain. Tour. 2007, 15, 418-437. [CrossRef]

9. Hopkins, D.; Maclean, K. Climate change perceptions and responses in Scotland's ski industry. Tour. Geogr. 2014, 16, 400-414. [CrossRef]

10. Scott, D.; McBoyle, G.; Minogue, A.; Mills, B. Climate change and the sustainability of ski-based tourism in Eastern North America: A reassessment. J. Sustain. Tour. 2006, 14, 376-398. [CrossRef]

11. Scott, D.; McBoyle, G.; Minogue, A. Climate change and Quebec's ski industry. Glob. Environ. Chang. 2007, 17, 181-190. [CrossRef]

12. Scott, D.; Dawson, J.; Jones, B. Climate change vulnerability of the US Northeast winter recreation-tourism sector. Mitig. Adapt. Stratrg. Glob. Chang. 2008, 13, 577-596. [CrossRef]

13. Rutty, M.; Scott, D.; Johnson, P.; Jover, E.; Pons, M.; Steiger, R. Behavioral adaptation of skiers to climatic variability and chance in Ontario, Canada. J. Outdoor Recr. Tour. 2015, 11, 13-21. [CrossRef]

14. Fukushima, T.; Kureha, M.; Ozaki, N.; Fujimori, Y.; Harasawa, H. Influences of air temperature change on leisure industries: Case study on ski activities. Mitig. Adapt. Strateg. Glob. Chang. 2002, 7, 173-189. [CrossRef]

15. Heo, I.; Lee, S. The impact of climate change on ski industries in South Korea. In the case of the Yongpyong ski resort. J. Korean Geogr. Soc. 2008, 43, 715-727.

16. Pickering, C.M.; Buckley, R.C. Climate response by the ski industry: The shortcomings of snowmaking for Australian resorts. Ambio 2010, 38, 430-438. [CrossRef]

17. Hendrikx, J.; Zammit, C.; Hreinsson, E.Ö.; Becken, S. A comparative assessment of the potential impact of climate change on the ski industry in New Zealand and Australia. Clim. Chang. 2013, 119, 965-978. [CrossRef]

18. Elsasser, H.; Bürki, R. Climate change as a threat to tourism in the Alps. Clim. Res. 2002, 20, $253-257$. [CrossRef] 
19. Scott, D.; McBoyle, G. Climate change adaptation in the ski industry. Mitig. Adapt. Strateg. Glob. Chang. 2007, 12, 1411-1431. [CrossRef]

20. Scott, D.; McBoyle, G.; Mills, B. Climate change and the skiing industry in southern Ontario (Canada): exploring the importance of snowmaking as a technical adaptation. Clim. Res. 2003, 23, 171-181. [CrossRef]

21. Hennessy, K.J.; Whetton, P.H.; Walsh, K.; Smith, I.N.; Bathols, J.M.; Hutchinson, M.; Sharples, J. Climate change effects on snow conditions in mainland Australia and adaption at ski resorts through snowmaking. Clim. Res. 2008, 35, 255-277. [CrossRef]

22. Morrison, C.; Pickering, C.M. Perceptions of climate change impacts, adaptation and limits to adaptations in the Australian Alps: The ski-tourism industry and key stakeholders. J. Sustain. Tour. 2013, 21, 173-191. [CrossRef]

23. Dawson, J.; Scott, D. Managing for climate change in the alpine ski sector. Tour. Manag. 2013, 35, $244-254$. [CrossRef]

24. Hendrikx, J.; Hreinsson, E.Ö. The potential impact of climate change on seasonal snow in New Zealand: Part II-industry vulnerability and future snowmaking potential. Theor. Appl. Climatol. 2012, 110, 619-630. [CrossRef]

25. Vlés, V. Ski resorts in crisis and territorial construction in French Catalonia. J. Alp. Res. 2012, 100-2, 2-11. [CrossRef]

26. Abegg, B.; Agrawala, S.; Crick, F.; de Montfalcon, A. Climate change impacts and adaptation in winter tourism. In Climate Change in the European Alps; Agrawala, S., Ed.; OECD: Paris, France, 2007; pp. $25-60$.

27. Hahn, F. Innevamento Artificiale Nelle Alpi. Una Relazione Specifica; CIPRA: Schaan, Liechtenstein, 2004. Available online: http:/ / www.cipra.org/it/pubblicazioni/2709 (accessed on 10 February 2016). (In Italian)

28. Steiger, R.; Mayer, M. Snowmaking and climate change. Mt. Res. Dev. 2008, 28, 292-298. [CrossRef]

29. Steiger, R.; Stötter, J. Climate change impact assessment of ski tourism in Tyrol. Tour. Geogr. 2013, 15, 577-600. [CrossRef]

30. World Tourism Organization (UNWTO); United Nations Environment Programme (UNEP). Making Tourism More Sustainable - A Guide for Policy Makers; UNWTO: Madrid, Spain; UNEP: Paris, France, 2005.

31. CIPRA. Turismo nel Cambiamento Climatico. Una Relazione Specifica della CIPRA; CIPRA: Schaan, Liechtenstein, 2011. Available online: http://www.cipra.org/it/dossiers/20 (accessed on 10 February 2016). (In Italian)

32. Teich, M.; Lardelli, C.; Bebi, P.; Gallati, D.; Kytzia, S.; Pohl, M.; Pütz, M.; Rixen, C. Kli-Mawandel und Wintertourismus: Ökonomische und Ökologische Auswirkungen von Technischer Beschneiung; Forschungsanstalt für Wald, Schnee und Landschaft WSL: Birmensdorf, Switzerland, 2007. (In German)

33. Trawöger, L. Convinced, ambivalent or annoyed: Tyrolean ski tourism stakeholders and their perceptions of climate change. Tour. Manag. 2014, 40, 338-351. [CrossRef] [PubMed]

34. Wolfsegger, C.; Gössling, S.; Scott, D. Climate change risk appraisal in the Austrian Ski industry. Tour. Rev. Int. 2008, 12, 13-23. [CrossRef]

35. Bicknell, S.; McManus, P. The canary in the Coalmine: Australian ski resorts and their response to climate change. Geograph. Res. 2006, 44, 386-400. [CrossRef]

36. Putz, M.; Gallati, D.; Kytzia, S.; Elasses, H.; Lardelli, C.; Teich, M.; Waltert, F.; Rixen, C. Winter tourism, climate change, and snowmaking in the Swiss Alps: Tourists' attitudes and regional economic impacts. Mt. Res. Dev. 2011, 31, 357-362. [CrossRef]

37. Hopkins, D. The sustainability of climate change adaptation strategies in New Zealand's ski industry: A range of stakeholder perceptions. J. Sustain. Tour. 2014, 22, 107-126. [CrossRef]

38. Ayuso, S. Adoption of voluntary Environmental tools for sustainable tourism: Analyzing the experience of Spanish hotels. Corp. Soc. Responsib. Environ. Manag. 2006, 13, 207-220. [CrossRef]

39. Bader, E.E. Sustainable hotel business practices. J. Retail Leis Prop. 2005, 5, 70-77. [CrossRef]

40. Radwan, H.R.I.; Jones, E.; Minoli, D. Solid waste management in small hotels: A comparison of green and non-green small hotels in Wales. J. Sustain. Tour. 2012, 20, 533-550. [CrossRef]

41. Park, J.; Kim, H.J.; McCleary, K.W. The Impact of Top Management's Environmental Attitudes on Hotel Companies' Environmental Management. J. Hosp. Tour. Res. 2014, 38, 95-115. [CrossRef]

42. Bohdanowicz, P. European Hoteliers' Environmental Attitudes: Greening the Business. Cornell Hosp. Quart. 2005, 46, 188-204. [CrossRef]

43. Bohdanowicz, P. Environmental awareness and initiatives in the Swedish and Polish hotel industries-Survey results. Int. J. Hosp. Manag. 2006, 24, 662-682. [CrossRef] 
44. International Standardization for Organization (ISO). ISO 14001:2015. Environmental Management System-Requirements with Guidance for Use; ISO: Geneva, Switzerland, 2015.

45. European Economic Community. Regulation (EC) No 1221/2009 of the European Parliament and of the Council of 25 November 2009 on the Voluntary Participation by Organisations in a Community Eco-management and Audit Scheme (EMAS), Repealing Regulation (EC) No 761/2001 and Commission Decisions 2001/681/EC and 2006/193/EC. Available online: http:/ / eur-lex.europa.eu/legal-content/EN/ TXT/HTML/?uri=CELEX:32009R1221\&from=en (accessed on 8 August 2016).

46. Rodríguez-Antòn, J.M.; del Mar Alonso-Almeida, M.; Celemín, M.S.; Rubio, L. Use of different sustainability management systems in the hospitality industry. The case of Spanish hotels. J. Clean. Prod. 2012, 22, 76-84. [CrossRef]

47. International Standardization for Organization (ISO). Environmental Management System-Requirements with Guidance for Use; ISO 14001:2004; ISO: Geneva, Switzerland, 2004.

48. Gonzáles-Benito, J.; Gonzáles-Benito, O. An analysis of the relationships between environmental motivations and ISO 14001 Certification. Br. J. Manag. 2005, 16, 133-148. [CrossRef]

49. Perotto, E.; Canziani, R.; Marchesi, R.; Butelli, P. Environmental performances, indicators and measurement uncertainty in EMS context: A case study. J. Clean. Prod. 2008, 16, 517-530. [CrossRef]

50. Chan, E.S.W.; Wong, S.C.K. Motivations for ISO 14001 in the hotel industry. Tour. Manag. 2006, 27, 481-492. [CrossRef]

51. Bohdanowicz, P.; Zientara, P. Corporate Social Responsibility in Hospitality: Issues and Implications. A Case Study of Scandic. Scand. J. Hosp. Tour. 2008, 8, 271-293. [CrossRef]

52. Chan, E.S.W. Barriers to EMS in the hotel industry. Int. J. Hosp. Manag. 2008, 27, 187-196. [CrossRef]

53. Chan, E.S.W.; Hawkins, R. Application of EMSs in a hotel context: A case study. Int. J. Hosp. Manag. 2012, 31, 405-418. [CrossRef]

54. Sagarra-Oña, M.; Peiró-Signes, À.; Verma, R.; Miret-Pastor, L. Does environmental certification help the economic performances of hotels? Evidence from the Spanish hotel industry. Cornell Hosp. Quart. 2012, 53, 242-256. [CrossRef]

55. Marimon, F.; Llach, J.; Bernardo, M. Comparative analysis of diffusion of the ISO 14001 standard by sector of activity. J. Clean. Prod. 2011, 19, 1734-1744. [CrossRef]

56. Accredia-Ente Italiano di Accreditamento. Banche Dati sulle Organizzazioni con Sistema di Gestione Certificato. Available online: http:/ /www.accredia.it (accessed on 20 April 2016). (In Italian)

57. ISPRA. Elenco delle Organizzazioni Registrate EMAS. Available online: http://www.isprambiente.gov.it/ it/certificazioni/emas/elenco-organizzazioni-registrate-emas (accessed on 19 April 2016). (In Italian)

58. Buckley, R. Tourism Ecolabels. Ann. Tour. Res. 2002, 29, 183-208. [CrossRef]

59. Sasidharan, V.; Sirakaya, E.; Kerstetter, D. Developing countries and tourism ecolabels. Tour. Manag. 2002, 23, 161-174. [CrossRef]

60. Dabeva, T. The role of international eco certification system in the hotel industry. In Proceedings of the Sixth Black Sea Tourism Forum, Varna, Bulgaria, 2-4 October 2013; pp. 149-160.

61. Font, X. Environmental certification in tourism and hospitality: Progress, process and prospects. Tour. Manag. 2002, 23, 197-205. [CrossRef]

62. Plüss, C.; Zotz, A. Sustainability in Tourism. A Guide through the Label Jungle; Naturefriends International: Vienna, Austria, 2012.

63. Nicholls, S.; Kang, S. Going green: The adoption of environmental initiatives in Michigan's lodging sector. J. Sustain. Tour. 2012, 20, 953-974. [CrossRef]

64. Beltramo, R.; Giovinazzo, A.; Duglio, S. Modelling of environmental and economic costs and benefits of the management of the mountain huts of the Aosta Valley-Italy. J. Commun. Sci. Technol. Qual. 2006, 45, 81-97.

65. Duglio, S.; Beltramo, R. Quality assessment in the Italian mountain huts. Eur. J. Tour. Res. 2014, 8, 115-142.

66. Campisi, B.; Marinatto, F.; Bogoni, P. The European Ecolabel in the Tourist Sector: An Analysis of the Italian Experience of Mountain Huts. In Pathways to Environmental Sustainability; Salomone, R., Saija, G., Eds.; Springer: Berlin, Germany, 2014; pp. 257-266.

67. Beltramo, R.; Pandolfi, E.; Duglio, S. La creazione di un Sistema di Gestione Ambientale Multisito come promozione del turismo montano. Ambiente 2005, 6, 591-597. (In Italian)

68. Ayala, H. Ecoresort: A "green" masterplan for the international resort industry. Int. J. Hosp. Manag. 1995, 14, 351-374. [CrossRef] 
69. Varley, P.; Medway, D. Ecosophy and tourism: Rethinking a mountain resort. Tour. Manag. 2011, 32, $902-911$. [CrossRef]

70. Smerecnik, K.R.; Andersen, P.A. The diffusion of environmental sustainability innovations in North American hotels and ski resorts. J. Sustain. Tour. 2011, 19, 171-196. [CrossRef]

71. Little, C.M.; Needham, M.D. Skier and snowboarder motivations and knowledge related to Voluntary Environmental Programs at an alpine ski area. Environ. Manag. 2011, 48, 895-909. [CrossRef] [PubMed]

72. Needham, M.D.; Little, C.M. Voluntary environmental programs at an alpine ski area: Visitor perceptions, attachment, value orientations, and specialization. Tour. Manag. 2013, 35, 70-81. [CrossRef]

73. Cohen, B. Going green: A bumpy run for ski areas. LOHAS J. 2001, 2, 43-46.

74. Rivera, J.; de Leon, P.; Koeber, C. Is greener whiter yet? The Sustainable Slopes Program after five years. Policy Stud. J. 2006, 34, 195-221. [CrossRef]

75. George, A. Managing ski resorts: Perceptions from the field regarding the sustainable slopes charter. Manag. Leis 2003, 8, 41-46. [CrossRef]

76. George, A. Managing ski resorts: The National Ski Areas Association (NSAA) of the United States' 2001 and 2002 Annual Progress Reports on the Environmental Charter and the reaction from conservations groups. Manag. Leis. 2004, 9, 59-67. [CrossRef]

77. Luthe, T. Label Touristiques Européens. In Proceedings of Les Stations de Montagne en Transition, Label Touristiques et Durabilité, La Manège, Chambery, France, 19 November 2013. (In French).

78. Luthe, T. Measuring, Labeling and Communicating Sustainability in Alpine Tourism. In Proceedings of the Comparison and Classification of Existing Labels-Towards a Common Standard, SMAT Symposium, Chur, Switzerland, 15-16 January 2015.

79. International Standardization for Organization (ISO). Energy Management Systems—Requirements with Guidance for Use; ISO 50001:2011; ISO: Geneva, Switzerland, 2011.

80. Assolombarda; Università Commerciale Luigi Bocconi-IEFE. ISO 14001:2015. Le novità della norma e le linee guida per l'applicazione dei nuovi requisiti. Ambient. Sicur. 2015, 20, 1-103. (In Italian)

81. Nicoletti, G.M.; Di Noia, A.E. Risk Management: A proposal for the practice of the "new" ISO 14001:2015. In Risk Management: Perspectives and Open Issues. A Multi-Disciplinary Approach; Cantino, V., de Vincentiis, P., Racca, G., Eds.; McGraw-Hill Education: London, UK, 2016; pp. 608-621.

82. NSAA-National Ski Areas Association. Sustainable Slopes. The Environmental Charter for Ski-Areas; NSAA: Lakewood, CA, USA, 2005. Available online: https://www.nsaa.org/media/20665/charter.pdf (accessed on 3 December 2015).

83. Mentil, K.; Grabenweger, E. "Alpine-Pearls-Hosts": A cooperation with family enterprises. A field report of Alpine Pearls. J. Co-oper. Org. Manag. 2015, 3, 96-97. [CrossRef]

84. Alpine Pearls. Catalogo dei Criteri; Alpine Pearls: Werfenweng, Austria, 2014; Available online: http://www.alpine-pearls.com/fileadmin/userdaten/Downloadbereich/Downloads_IT/Catalogo_dei_ criteri_NUOVO.pdf (accessed on 3 December 2015). (In Italian)

85. Association Mountain Riders. Cahier des Charges-Flocon Vert; Association Mountain Riders: Chambéry, France, 2015. Available online: http://www.mountain-riders.org/FLOCONVERT/CahierDesChargesFloconVert.pdf (accessed on 4 December 2015). (In French)

86. Geerts, W. Environmental certification schemes: Hotel managers' views and perceptions. Int. J. Hosp. Manag. 2014, 39, 87-96. [CrossRef]

87. Green Globe Certification 2016. Available online: http://greenglobe.com/ (accessed on 30 June 2016).

88. International Standardization for Organization (ISO). Guidelines for Auditing Management Systems; ISO 19011:2011; ISO: Geneva, Switzerland, 2011.

89. Pro Natura Pro Ski Foundation. Auditing in Ski Areas. A Guide to Ecological Upgrading; Pro Natura Pro Ski Foundation: Vaduz, Liechtenstein, 2009. Available online: http://www.skiaudit.info/media/files/pdf/ short_version_ski_auditing_english.pdf (accessed on 14 January 2016).

(C) 2016 by the authors; licensee MDPI, Basel, Switzerland. This article is an open access article distributed under the terms and conditions of the Creative Commons Attribution (CC-BY) license (http:/ / creativecommons.org/licenses/by/4.0/). 